7. Reprod. Fert. (1971) 25, 21-28

\title{
HISTOLOGICAL CHANGES IN THE SEMINIFEROUS TUBULES OF IMMATURE MICE FOLLOWING ADMINISTRATION OF GONADOTROPHINS
}

\author{
A. G. DAVIES \\ Department of Physiology, Medical School, Birmingham 15
}

(Received 13th April 1970)

\begin{abstract}
Summary. Effects of gonadotrophin administration were investigated histologically in the testes of neonatal mice. The hormones used were human pituitary follicle-stimulating hormone (FSH), containing $20 \%$ of luteinizing hormone, and human chorionic gonadotrophin (HCG).

FSH treatment increased the numbers of nuclei of spermatogonia and of Sertoli-cell precursors per mouse and caused an even greater increase in the volume of eosinophilic intratubular material. It is thought that the greater part of this material was syncytial cytoplasm of the Sertoli-cell precursors.
\end{abstract}

Administration of HGG did not have these effects nor modify the effects of FSH treatment.

\section{INTRODUCTION}

Previous studies have given rise to conflicting reports about the effects of follicle-stimulating hormone (FSH) on the germinal cells of the mammalian testis. Indeed, there is still doubt as to whether, in the absence of luteinizing hormone (LH), FSH has any effect on these cells (Glermont \& Harvey, 1967). On the other hand, FSH does appear to have a poorly defined stimulatory effect on Sertoli cells (Murphy, 1965). In this paper, the effects of a crude preparation of FSH on both types of cell are examined, and possible interactions between the effects of FSH and human chorionic gonadotrophin (HCG) are tested.

\section{MATERIALS AND METHODS}

\section{Animals}

Four boxes of GFW mice were used. Each box contained two lactating females and twelve male young fostered within $24 \mathrm{hr}$ of birth. On the 6th day after birth, three young were removed from each of these foster-litters, leaving the nine young of most uniform body weight.

\section{Hormones}

Human pituitary FSH was extracted and assayed by the methods described by Butt, Grooke \& Gunningham (1961). The material was fraction GPl, the 
potency of which was $700 \mathrm{i}$.u. FSH and $140 \mathrm{i}$.u. L.H activity per mg. The potency of the HCG (Paines \& Byrne Ltd, Greenford, Middlesex) was $<15$ i.u. FsH and $>1500$ i.u. LH per $\mathrm{mg}$.

\section{Experimental design}

FSH and HGG were injected once daily for 3 days starting on the 6th day after birth. Nine animals in each of four replicates of a randomized block received subcutaneous injections of $0.05 \mathrm{ml}$ of distilled water containing amounts of gonadotrophin as shown in Table 1.

TABLE 1

EXPERIMENTAL DESIGN

\begin{tabular}{c|c|c}
\hline Animal & No. i.u. FSH/day & No. i.u. $\mathrm{HGG} /$ day \\
\cline { 1 - 2 } 1 & 0 & 0 \\
2 & 0 & 1 \\
3 & 0 & 5 \\
4 & 1 & 0 \\
5 & 1 & 1 \\
6 & 1 & 5 \\
7 & 5 & 0 \\
8 & 5 & 1 \\
9 & 5 & 5 \\
\hline
\end{tabular}

\section{Histological processing}

When the mice were 9 days old, they were killed by cervical dislocation and the testes were weighed. After fixation in Sanfelice's fluid for 20 to $24 \mathrm{hr}$ and embedding in paraffin wax, testes were cut transversely at $4 \mu$. Sections were taken at random from five different levels of one testis of each animal and stained with Weigert's iron haematoxylin and eosin.

\section{Histometric methods}

Volume of tissue elements. The structures at 200 random points in each section (i.e. 1000 points per animal) were noted, using a magnification of $\times 1000$ and an eye-piece graticule of twenty-five randomly distributed dots. All the structures observed were scored under the following headings:

(i) nucleus of spermatogonium

(ii) nucleus of Sertoli-cell precursor

(iii) nucleus of resting primary spermatocyte

(iv) nucleus of leptotene or zygotene primary spermatocyte

(v) basement membrane (including lamina propria) of tubule

(vi) interstitial tissue (including Leydig cell nucleus and cytoplasm, connective tissue and blood vessel)

(vii) intratubular eosinophilic material (including cytoplasm of germinal cell and Sertoli-cell precursor)

The volume of each type of structure was calculated by multiplying together the proportion of points at which the structure was recorded and the combined 
volume of the particular animal's testes without their tunicae. It was first necessary to determine the relative weight of tunica albuginea and the specific gravity of testicular tissue.

Twenty pairs of fresh testes were weighed before and after removal of the tunicae. Untreated animals, ranging in age from 8 to 11 days, were used. As there was a significant correlation between the weights of testes with and without tunicae ( $\mathrm{r}=0.994, P \leqslant 0.001)$, the following linear regression equation was calculated:

$$
\mathrm{x}=0.932 \mathrm{y}-0.484
$$

where $\mathrm{x}=$ the weight of a pair of testes after removal of their tunicae and $\mathrm{y}=$ the weight before removal.

The specific gravity of fresh testis was calculated from the weights of twentyfive testes in air and during immersion in saline, using Archimedes' principle. Tissue from untreated 9-day-old animals was used.

Diameter of tubules. Diameters were measured with an eye-piece graticule calibrated against a stage micrometer. At three levels in the testis of each animal, the minimum diameter of six randomly selected tubules, cut in transverse section, was measured. The mean of these eighteen measurements was then calculated.

Shrinkage during processing. In order to calculate the numbers of intratubular cells, it was necessary to estimate the degree of shrinkage of testis during histological processing. This was done by preparing serial longitudinal sections of twenty testes from 9-day-old mice. This tissue was processed in the same way as the tissue from treated animals and cut at $6 \mu$. The shape of the testis was assumed to be an ellipsoid and the volume of the processed tissue was calculated from the formula $\frac{4}{3} \pi \mathrm{Rr}^{2}$, where $\mathrm{R}=$ the largest longitudinal radius found in the serial sections and $\mathrm{r}=$ the largest transverse radius.

A correction had to be applied to the volumes so calculated to allow for rents in the sections caused by shrinkage. In each of the twenty testes, 100 random points were examined under the microscope and the numbers of points overlying stained tissue and unstained gaps were noted. The mean proportion of stained tissue was $92 \%$. As the tunica had no rents, this figure was used to correct the volume of the testis without the tunica.

The ratio of corrected testicular volume after processing to original volume (the shrinkage factor) was calculated thus:

$$
\text { Shrinkage factor }=\frac{\text { Gorrected volume after processing }}{\text { Fresh weight } \div \text { Specific gravity of fresh tissue }}
$$

Volumes of cell nuclei. In one section from one testis of each injected animal, five spermatogonia were selected at random and the diameter of their nuclei was measured in two directions at right angles. Nuclei which had not been cut near the equator (i.e. with diameters of less than $5 \mu$ ) were rejected. Nuclear volume was calculated from the formula $4 / 3 \pi r^{3}$, where $r=$ the mean radius determined from the ten diameter measurements made in the testis. As an analysis of variance did not indicate that treatment with hormones had significantly affected nuclear volume, or that there was a significant difference between foster-litters, the volumes from all thirty-six animals were pooled. 
Similarly, in one section from one testis of each animal the maximum and minimum diameters of the nuclei of five Sertoli-cell precursors were measured. As these nuclei were not iso-diametric, only nuclei appearing in longitudinal section were used. In the calculation of volume, these nuclei were assumed to be ellipsoidal. Again, as there were not significant differences in volume due to hormonal treatment or between foster-litters, the nuclear volumes were pooled.

The nuclei of resting primary spermatocytes and of leptotene/zygotene spermatocytes were assumed to be spherical and their volumes calculated from measurements of two diameters in five cells of each category from eight animals.

Cell numbers. The number of each type of intratubular cell in each animal was calculated as follows:

Number $=\frac{\text { Volume of pair of fresh testes without tunicae } \times \text { Shrinkage factor }}{\text { Volume of one nucleus in processed tissue }}$

\section{RESULTS}

\section{Testicular weight}

Treatment with FSH caused a statistically significant increase in testicular weight. The mean combined weight of the testes of animals treated only with water or HCG was $7.0 \mathrm{mg}$, whereas the weights in animals treated with small

TABLE 2

ANALYSIS OF VARIANCE IN COMBINED TESTICULAR WEIGHT

\begin{tabular}{|c|c|c|c|c|c|}
\hline Source & $\begin{array}{l}\text { Degrees of } \\
\text { freedom }\end{array}$ & $\begin{array}{l}\text { Sum of } \\
\text { squares }\end{array}$ & $\begin{array}{c}\text { Mean } \\
\text { square }\end{array}$ & $F$ & $\mathbf{P}$ \\
\hline $\begin{array}{l}\text { Between foster-litters } \\
\text { Between FSH treatments } \\
\text { Between HCG treatments } \\
\text { Interaction of FSH and HCG } \\
\text { Residual }\end{array}$ & $\begin{array}{r}3 \\
2 \\
2 \\
4 \\
24 \\
35\end{array}$ & $\begin{array}{r}16 \cdot 63 \\
85 \cdot 32 \\
1 \cdot 21 \\
3 \cdot 69 \\
31 \cdot 44 \\
138 \cdot 29\end{array}$ & $\begin{array}{r}5.54 \\
42.66 \\
0.60 \\
0.92 \\
1.31\end{array}$ & $\begin{array}{r}4 \cdot 229 \\
32.564 \\
0.458 \\
0 \cdot 702\end{array}$ & $\begin{array}{l}<0.025 \\
<0.001 \\
>0.20 \\
>0.20\end{array}$ \\
\hline Total & 35 & $138 \cdot 29$ & & & \\
\hline
\end{tabular}

and large doses of FSH were $9.6 \mathrm{mg}$ and $10.7 \mathrm{mg}$, respectively. The same statistical method was used to analyse all effects of gonadotrophin treatment. To illustrate the method, the analysis of variance of testicular weight is given (Table 2) but for other effects, only the levels of significance of variance ratios are quoted if the $P$ values are $<0.05$.

\section{Volume of testes without tunicae}

After calculating, from the regression given above, the weight of testes without tunicae in each injected animal, the volume was calculated by dividing this corrected testicular weight by the specific gravity, which was found to be 1.14. The results of analysis of these volumes were similar to those given by the 
testicular weights. FsH treatment was followed by an increase in the volume $(P<0.001)$ and there was a significant effect between litters $(P<0.025)$.

\section{Animal weight}

Hormonal treatment did not affect body weight significantly. The only significant finding was a between-litter difference $(P<0 \cdot 001)$.

\section{Tubular diameter}

The mean tubular diameter in processed tissue was greater in animals receiving the FsH preparation (control $57.8 \mu$, small dose $64 \cdot 0 \mu$, large dose $65.9 \mu$, $P<0.01)$.

\section{Numbers of intratubular nuclei}

The volumes of the intratubular nuclei in processed tissue are given in Table 3. In twenty testes, the ratio of volume after processing to original volume was

TABLE 3

NUGLEAR VOLUMES IN PROCESSED TISSUE

\begin{tabular}{l|c|c}
\hline \multicolumn{1}{c|}{ Type of cell } & $\begin{array}{c}\text { Mean volume of } \\
\text { nucleus }\left(\mu^{3}\right)\end{array}$ & $\begin{array}{c}\text { No. of } \\
\text { nuclei measured }\end{array}$ \\
\hline Spermatogonium & 245 & 180 \\
Sertoli-cell precursor & 134 & 180 \\
Resting primary spermatocyte & 131 & 40 \\
Leptotene/zygotene spermatocyte & 142 & 40 \\
\hline
\end{tabular}

TABLE 4

MEAN NUMBERS OF NUGLEI OF GERMINAL CELLS AND SERTOLI-GELL PREGURSORS PER ANIMAL

\begin{tabular}{|c|c|c|c|c|}
\hline \multirow[t]{2}{*}{ Type of cell } & \multicolumn{3}{|c|}{$\begin{array}{c}\text { Mean no. of nuclei }\left(\times 10^{-3}\right) / \text { animal } \\
\text { at varying doses of } \mathrm{FSH} / \text { day }\end{array}$} & \multirow[t]{2}{*}{$\begin{array}{l}\text { P. for FsH } \\
\text { effect }\end{array}$} \\
\hline & 0 i.u. & $1 i . u$. & 5 i.u. & \\
\hline $\begin{array}{l}\text { Spermatogonium } \\
\text { Sertoli-cell precursor } \\
\text { Resting primary spermatocyte } \\
\text { Leptotene/zygotene spermatocyte }\end{array}$ & $\begin{array}{r}1516 \\
5573 \\
112 \\
74\end{array}$ & $\begin{array}{r}2018 \\
6984 \\
218 \\
236\end{array}$ & $\begin{array}{r}2373 \\
8289 \\
109 \\
160\end{array}$ & $\begin{array}{l}<0.001 \\
<0.001 \\
>0.20 \\
>0.05\end{array}$ \\
\hline
\end{tabular}

$0 \cdot 516 \pm 0.020$ (mean \pm S.E.). Animals which had been treated with FSH had larger numbers of nuclei of spermatogonia and Sertoli-cell precursors (Table 4). HCG did not have a significant effect. There were significant differences in the numbers of nuclei of spermatogonia and Sertoli-cell precursors between litters $(P<0.025)$.

\section{Volumes of other tissue elements}

Animals treated with FSH had larger volumes of intratubular eosinophilic material and tubular basement membrane (Table 5). HGG did not have a 
TABLE 5

\begin{tabular}{|c|c|c|c|c|}
\hline MEAN VOLUMES OF & $\begin{array}{l}\text { TESTIGULAR } \\
\left(\mathrm{MM}^{3} \text { OF FRE }\right.\end{array}$ & $\begin{array}{l}\text { TISSUE } \\
\text { SSH TISSU }\end{array}$ & $\begin{array}{l}\text { ELEMENTS } \\
\text { UE) }\end{array}$ & PER ANIMAL \\
\hline \multirow[t]{2}{*}{ Tissue element } & \multicolumn{3}{|c|}{$\begin{array}{l}\text { Mean vol. of tissue/animal at varying } \\
\text { doses of } \mathrm{FSH} / \text { day }\end{array}$} & \multirow[t]{2}{*}{$\begin{array}{l}\text { P for FsH } \\
\text { effect }\end{array}$} \\
\hline & 0 i.u. & 1 i.u. & $5 i . u$. & \\
\hline $\begin{array}{l}\text { Intratubular material } \\
\text { Basement membrane } \\
\text { Interstitial tissue }\end{array}$ & $\begin{array}{l}2 \cdot 276 \\
0.524 \\
0.477\end{array}$ & $\begin{array}{l}3.509 \\
0 \cdot 674 \\
0.551\end{array}$ & $\begin{array}{l}3.833 \\
0 \cdot 808 \\
0.609\end{array}$ & $\begin{array}{l}<0.001 \\
\leqslant 0.001 \\
>0.05\end{array}$ \\
\hline
\end{tabular}

significant effect. The between-litter differences in the volumes of intratubular material and interstitial tissue were significant $(P<0.001$ and $P<0.01)$.

\section{DISGUSSION}

The seminiferous tubules of neonatal mice contain only the nuclei and cytoplasm of germinal cells and of Sertoli-cell precursors, as no lumina have yet formed. As the cell membranes could not be seen distinctly, it was not possible to relate the cytoplasmic material under a point on the graticule to a particular nucleus. In treated and in control animals, the intratubular cytoplasm occupied a larger volume than the total volume occupied by intratubular nuclei, and FSH treatment was followed by a greater absolute and a greater proportional increase in the volume of the cytoplasm. This could have been due to an increase in the ratio of cytoplasm to nucleus in the germinal cells, in the Sertoli-cell precursors, or in both. It is probable that the increase in the amount of cytoplasm following FSH treatment was chiefly due to an increase in Sertoli-cell precursor cytoplasm as studies of neonatal rat testis under the electron microscope show that the greater part of the intratubular cytoplasm is Sertoli-cell precursor cytoplasm (L. L. Franchi, personal communication).

Previous investigations have not solved the problem of whether FSH affects testicular germinal cells in the absence of $\mathbf{L H}$. Some of the studies performed in hypophysectomized rats have suggested that FSH, acting alone, may stimulate multiplication or reduce degeneration of spermatogonia and perhaps of spermatocytes (Woods \& Simpson, 1961; Ortavant \& Courot, 1967; Lostroh, 1969). In hypophysectomized lambs, Gourot (1967) found that FsH administration increased the numbers of spermatogonia. However, Harvey (1965) found no evidence of this in hypophysectomized adult rats, neither did Steinberger, Steinberger \& Perloff (1964) in immature rat testes maintained in organ culture.

The contamination of one gonadotrophin by another is a source of difficulty when trying to assess the effects caused by each. Glermont \& Harvey (1967) attributed any stimulating effect of FSH on spermatogenesis to contaminating LH. Von Berswordt-Wallrabe, Steinbeck \& Neumann (1968) came to the same conclusion when they found that the effects of FsH on the germinal cells of hypophysectomized adult male rats were abolished by the anti-androgen, 
cyproterone. On the other hand, Lostroh, Johnson \& Jordan (1963) found that administration of anti-LH did not modify the effects of FSH on the division of spermatogonia. It is thought that the stimulatory effect of the impure preparation of FSH used in the present study was probably due to FSH alone, but the possibility that contaminating $\mathbf{L H}$ had a synergistic effect has not been eliminated. If $\mathrm{LH}$ was synergistic, the amount producing a maximum effect must be small because HCG caused no further augmentation.

Other factors which may contribute to the divergence of evidence cited above are that gonadotrophin effects may differ between species and with the level of sexual maturity of an animal. This possibility is suggested by the work of Ortavant, Courot \& de Reviers (1969), who found that FsH stimulated spermatogenesis in hypophysectomized, prepuberal rats, but not in hypophysectomized adults. Furthermore, Kuehl, Patanelli, Tarnoff \& Humes (1970) have reported that FSH stimulates the production of adenosine $3^{\prime}, 5^{\prime}$-monophosphate in slices of testis from immature rats, but not in slices from intact adults.

In contrast to the conflicting reports of effects of FSH on germinal cells, previous workers agree that FSH has a stimulating action on the Sertoli-cell line (Lostroh et al., 1963; Steinberger et al., 1964; Lacy \& Lofts, 1965; Murphy, $1965)$ and the greater part of the large increase in eosinophilic material reported in this paper is thought to be due to an increase in the cytoplasm of Sertoli-cell precursors.

\section{AGKNOWLEDGMENTS}

The author wishes to thank Dr W. R. Butt and the Glinical Endocrinology Gommittee of the Medical Research Gouncil for the supply of FSH, and gratefully acknowledges the technical assistance of $\mathrm{Mr} \mathrm{T}$. Wafer and statistical advice given by Mr P. Bertrand.

\section{REFERENCES}

Butt, W. R., Grooke, A. G. \& Cunningham, F. J. (1961) Studies on human urinary and pituitary gonadotrophins. Biochem. F. 81, 596.

CLermont, Y. \& Harvey, S. C. (1967) Effects of hormones on spermatogenesis. In: Endocrinology of the Testis. Eds. G.E.W. Wolstenholme and Maeve O'Connor. Ciba Colloquium, Churchill, London.

Courot, M. (1967) Action des hormones gonadotropes et de la testostérone sur le testicule impubère. Archs Anat. microsc. 57, Suppl. 3-4, 7.

HARVEY, C. (1965) Effect of ICSH Or FSH on the number of germ cells in the seminiferous tubules of adult rats. Anat. Rec. 151, 359.

Kuehl, F. A., Pataneli, D. J., Tarnoff, J. \& Humes, J. L. (1970) Testicular adenyl cyclase: stimulation by pituitary gonadotrophins. Biol. Reprod. 2, 154.

LACY, D. \& Lorts, B. (1965) Studies on the structure and function of mammalian testis. I. Proc. R. Soc. $B, 162,188$.

LostroH, A.J. (1969) Regulation by FSH and ICSH (LH) of reproductive function in the immature male rat. Endocrinology, 85, 438.

Lostroh, A. J., Johnson, R. \& Jordan, C. W. (1963) Effects of ovine gonadotrophins and antiserum to interstitial cell-stimulating hormone on the testis of the hypophysectomised rat. Acta endocr., Copenh. 44, 536.

MURPHY, H. D. (1965) Intratesticular assay of follicle-stimulating hormone in hypophysectomised rats. Proc. Soc. exp. Biol. Med. 120, 671.

Ortavant, R. \& Courot, M. (1967) Action des hormones gonadotropes sur la lignée germinale mâle adulte. Archs Anat. microsc. 56, Suppl. 3-4, 111. 
Ortavant, R., Courot, M. \& DE Reviers, M. M. (1969) Activités spécifiques des différentes rsh et $\mathbf{L H}$ sur le testicule des mammifères. In: La spécificité zoologique des hormones hypophysaires et de leurs activités. Colloques int. Cent. natn. Rech. scient. 177.

Steingerger, E., Steingerger, A. \& Perloff, W. H. (1964) Initiation of spermatogenesis in vitro. Endocrinology, 74, 788.

Von Berswordt-Wallrabe, R., Steinbeck, H. \& Neumann, F. (1968) Effects of fsh on the testicular structure of rats. Endokrinologie, 53, 35.

Woods, M. C. \& Simpson, M. E. (1961) Pituitary control of the testis of the hypophysectomized rat. Endocrinology, 69, 91. 